\title{
Analisis Biaya Produksi Sebagai Dasar Pengambilan Keputusan Produksi Kecambah Di Home Industri Kecambah Rama Hulaan Gresik
}

\author{
LUKITA PERMANASARI
}

STAI Al-Azhar Menganti Gresik lukitapermanasiri@gmail.com

\section{Ayu Dwi Virdayani}

STAI Al-Azhar Menganti Gresik

Virdayani2I@gmail.com

\begin{abstract}
This research is a field research study using a qualitative approach. The data were collected using interview techniques to businessmen in the Sprouts Home Industry. The data that has been collected is then processed and analyzed by making calculations using the MOS (margin of safety) method. The results showed that there was an advantage that occurred in the production of sprouts due to increased sales and the amount of production, making the Rama Hulaan Sprouts Home Industry make a decision between increasing the amount of sprouts production or determining the amount of production. Between the two alternatives, the one that is profitable for the company must be selected. If the company decides to increase the amount of production, the production costs will also increase and the profit that will be obtained by the company will increase. If the company determines the amount of production, there will be no increase in production costs as well as no increase in profit in the coming year. From the comparative analysis between adding or determining the amount of production, the company should make a decision to increase the number of sprouts produced
\end{abstract}

Keywords: home industry, profit, production costs, margin of safety

Abstrak: Penelitian ini merupakan penelitian field reseach dengan menggunakan pendekatan kwalitatif. Data di humpun dengan menggunakan teknik wawancara kepada pelaku usaha Home Industri Kecambah. Data yang telah dikumpulkan kemudian di olah dan di analisis dengan cara membuat perhitungan dengan menggunakan metode MOS (margin of safety). Hasil penelitian menunjukkan adanya keuntungan yang terjadi pada produksi kecambah yang disebabkan meningkatnya penjualan dan jumlah produksi menjadikan Home Industri Kecambah Rama Hulaan mengambil keputusan antara 
menambah jumlah produksi kecambah atau menetapkan jumlah produksi. Diantara dua alternatif tersebut harus dipilih salah satu yang menguntungkan bagi perusahaan. Bila perusahaan memutuskan untuk menambah jumlah produksi maka akan bertambah pula biaya produksi dan semakin meningkatnya laba yang akan diperoleh oleh perusahaan. Jika perusahaan menetapkan jumlah produksi maka tidak ada kenaikan biaya produksi begitu pula tidak ada kenaikan laba di tahun yang akan datang. Dari analisa perbandingan antara menambah atau menetapkan jumlah produksi sebaiknya perusahaan mengambil keputusan untuk menambah jumlah kecambah yang di produksi.

Kata Kunci: home industri, laba, biaya produksi, margin of safety,

\section{A. Pendahuluan}

Pertumbuhan ekonomi di Indonesia sejak pertengahan lalu mengalami hambatan, hal ini disebabkan karena timbulnya krisis ekonomi dan dampak yang ditimbulkan dengan adanya krisis ekonomi tidak lagi terbatas pada gulung tikar sejumlah perusahaan atau di PHK-nya sejumlah karyawan. Perusahaan sebagai satu kesatuan ekonomi, pada umumnya didirikan dengan tujuan untuk mendapatkan keuntungan yang semaksimal mungkin. Dengan demikian manajemen di tuntut untuk dapat mengelola perusahaan sebaik mungkin dalam melaksanakan fungsi perencanaan, koordinasi, pengendalian serta pemanfaatan segala sumber daya dan faktor-faktor produksi yang ada secara efektif dan efisien. ${ }^{\mathrm{I}}$

Dalam usahanya untuk mencapai tujuan perusahaan tersebut, pihak manajemen seringkali dihadapkan kepada berbagai masalah dalam pengambilan keputusan. Manajemen harus dapat mengambil keputusan yang tepat antara berbagai macam alternatif keputusan yang akan dilaksanakan untuk waktu yang akan datang. Pihak manajemen harus menghadapi resiko yang ada, karena alternatif yang dipilih mungkin bukan alternatif yang terbaik. Agar dapat membuat keputusan yang tepat, pihak manajemen harus mengetahui dengan baik informasi-informasi yang dapat digunakan untuk menganalisis keputusan tersebut. ${ }^{2}$

\footnotetext{
1 Hartadi A Sarwono, "Profil Bisnis Usaha Mikro, Kecil Dan Menengah (Umkm)," Bank Indonesia Dan LPPI, 2015.

${ }^{2}$ Muhammad Kambali, "Paradigma Sistem Kapitalisme Dan Islam Tentang Welfare State," JES (Jurnal Ekonomi Syariah), 2019, https://doi.org/10.30736/jesa.v4i1.55.
}

Volume. 9/No. I/Januari 202I A1-Iqtishod|74 
Informasi akuntansi biaya merupakan salah satu alat informasi yang perlu dipertimbangkan untuk pengelolahan perusahaan, sebab dengan menggunakan akuntansi biaya akan dapat dipergunakan dalam pengambilan keputusan baik menjual atau memproses lebih lanjut, membeli atau membuat sendiri, menerima atau menolak pesanan khusus, menghentikan atau meneruskan suatu produk tertentu. Sedangkan keputusan penambahan atau penggantian aktiva tetap, keputusan pemilihan sumber dana yang diperlukan perusahaan untuk jangka panjang.

Dalam pengambilan keputusan menghentikan atau meneruskan suatu produk tertentu yang tidak mendatangkan laba secara riil dan dampak yang diakibatkan oleh adanya penghentian salah satu produk tersebut, perusahaan harus dapat menentukan analisis dengan biaya produksi. Manajemen harus dapat mengetahui biaya-biaya produksi yang dapat diperkecil. Profitabilitas perusahaan akan dapat dicapai pada alternatif dengan biaya terendah, sehingga menajemen harus membandingkan biaya produksi terendah. ${ }^{3}$

Biaya produksi dipergunakan untuk pengambilan keputusan yang menyangkut pemilihan berbagai alternatif tindakan bagi manajemen keputusan yang diambil oleh manajemen yang meliputi berbagai macam masalah dalam jangka waktu tertentu. Biasanya manajemen ingin menghentikan jenis produk yang merugi, pedoman untuk menghentikan atau meneruskan jenis produk tertentu adalah jika biaya produksi yang dapat dihindarkan oleh suatu jenis produk tertentu lebih kecil dari pada pendapatan yang dikorbankan jenis produk yang bersangkutan maka jenis produk tersebut harus dipertahankan. Sedangkan bila biaya produksi yang tidak dapat dihindarkan oleh jenis produk tertentu lebih besar dari pada pendapatan yang dikorbankan jenis produk yang bersangkutan maka jenis produk tersebut harus dihentikan.

Kecambah merupakan salah satu bahan yang banyak digunakan dalam masakan Indonesia karena memilki cita rasa yang lezat dan mengandung nilai gizi tinggi

\footnotetext{
${ }^{3}$ Dewan Standar Akuntansi Syariah IAI, "Standar Akuntansi Keuangan Syariah," Ikatan Akuntan Indonesia, 2016.
}

Volume. 9/No. I/Januari 202I A1-Iqtishod|75 
terutama vitamin E, bahan baku kecambah yaitu kacang hijau. Pada dasarnya proses pembuatan kecambah kacang hijau ini tidak terlalu sulit akan tetapi gaya hidup masyarakat di zaman modern seperti sekarang ini cenderung lebih memilih membeli daripada membuat sendiri. Keadaan ini dimanfaatkan oleh sebagaian orang untuk membuka perusahaan dan memproduksi kecambah dalam jumlah besar untuk dipasarkan diberbagai daerah yang tujuanya untuk mendapatkan keuntungan yang sebesar-besarnya.

Akan tetapi pada kenyataanya tidak semua perusahaan kecambah bisa memanajemen keuangan perusahaanya dengan baik, terkadang sebagian perusahaan merugi karena kurangnya perencanaan keuangan yang matang dalam perusahaan. Oleh karena itu diperlukan analisis biaya produksiyang matang agar perusahaan bisa melanjutkan produksinya yang lama dan meminimalisir terjadinya gulung tikar pada perusahaan.

\section{B. Kajian Pustaka}

\section{Pengertian Biaya Produksi}

Produksi dan biaya produksi bagaikan keping mata uang logam berisi dua. Jika produksi bebricara tentang nilai fisik penggunaan faktor produksi, biaya mengukurnya dengan nilai uang. Dalam ekonomi yang sudah modern, di mana peranan uang amat penting, maka ukuran efisiensi yang paling baik (walaupun bukan paling lengkap) adalah uang. Sesuatu yang efisien secara teknis, belum tentu secara finansial dan ekonomi menguntungkan. ${ }^{4}$ Membahas mengenai sifatsifat biaya produksi perusahaan di dalam masing-masing jangka waktu tersebut merupakan pokok persoalan yang akan di bahas dalam penelitian ini.

Biaya produksi dapat di definisikan sebagai semua pengeluaran yang dilakukan oleh perusahaan untuk memperoleh faktor-faktor ptoduksi dan bahan-

\footnotetext{
${ }^{4}$ Prathama Manurung, Pengantar Ilmu Ekonomi,(Jakarta: Lembaga Penerbit fakultas Ekonomi Universitas Indonesia,2008), II7.
}

Volume. 9/No. I/Januari 202I A1-Iqtishod|76 
Lukita Permanasari, Ayu Dwi Virdayani bahan mentah yang akan digunakan untuk menciptakan barang-barang yang diproduksikan perusahaan tersebut. ${ }^{5}$

Biaya produksi menurut Mulyadi merupakan biaya-baiaya yang terjadi untuk mengolah bahan baku menjadi produk jadi yang siap untuk dijual. ${ }^{6}$ Biaya produksi menurut Supriyono biaya produksi yaitu semua biaya yang berhubungan dengan fungsi produksi atau kegiatan pengolahan berhubungan dengan fungsi produksi atau kegiatan pengolahan bahan baku menjadi bahan selesai. ${ }^{7}$

Biaya produksi menurut Supomo merupakan bagian darai klasifikasi biaya yang berdasarkan fungsi kegiatan dengan proses pengolahan bahan baku menjadi produk selesai yang siap di jual. Biaya produksi dikelompokkan menjadi 3 yaitu:

a. Biaya Bahan Baku (BBB)

Adalah uang dari penggunaan bahan yang diolah menjadi produk selesai. Bahan yang diolah dapat dipisahkan menjadi bahan baku dan menjadi bahan jadi. Bahan baku merupakan bahan yang dapat didefinisikan dengan produk yang dihasilkan, nilainya relatif besar dan umumnya sifat bahan baku merupakan nilai uang dari biaya angkut bahan baku. Dan biaya bahan baku merupakan harga beli dan biaya angkut bahan baku. Sedangkan biaya bahan pembantu merupakan nilai uang dari biaya bahan pembantu yang digunakan dalam proses produksi dimana biaya termasuk elemen dari BOP, seperti biaya-biaya pesanan.

Semua biaya yang berkaitan dengan memperoleh biaya bahan dan untuk menempuh dalam keadaan siap di olah, merupakan unsur dari harga pokok bahan baku yang di beli. Harga pokok yang berdiri dari harga beli (harga tercantum dalam faktur pembelian) ditambah dengan biaya pembelian dan biaya-biaya dikeluarkan untuk menyiapkan bahan baku tersebut siap diolah.

\footnotetext{
${ }^{5}$ Sadono Sukirno, Mikro Ekonomi Teori Pengantar, (Jakarta: Rajawali Pers, 2009), 208.

${ }^{6}$ Mulyadi, Akuntansi Biaya,(Bandung:STIE, I99I), I4.

${ }^{7}$ Supriyono, Akuntansi Biaya Perencanaan dan Pengendalian, hal 19.
}

Volume. 9/No. I/Januari 202I A1-Iqtishod|77 
Adalah upah dari tenaga yang mengerjakan proses produksi. Biaya tenaga kerja merupakan harga yang dibebankan untuk tenaga kerja manusia dalam proses produksi. Biaya tenaga kerja dalam perusahaan biasanya dibagi menjadi dua yaitu: Biaya tenaga kerja langsung (BTKL), Biaya tenaga kerja tidak langsung (BTKTL).

Biaya tenaga kerja langsung adalah upah yang diberikan kepada tenaga kerja yang langsung mengerjakan pengolahan bahan menjadi produk selesai yang jasanya dapat diusut secara langsung pada produk dan upahnya merupakan bagian yang besar dalam memproduksi produk.

Dan biaya tenaga kerja tidak langsung adalah biaya yang dikeluarkan untuk tenaga kerja yang secara tidak langsung mengolah bahan baku dan biayab tenaga kerja tidak langsung ini dimasukkan kedalam elemen biaya overhead prusahaan.

c. Biaya Overhead (BOP)

Adalah bahan baku, tenaga kerja dan fasilitas produksi lainya, selain biaya bahan baku dan biaya tenaga kerja langsung. Penggolongan biaya-biaya produksi yang termasuk dalam biaya overhead perusahaan menurut sifatnya sebagai berikut:

I. Biaya bahan pembantu atau penolong

Penolong adalah bahan yang tidak menjadi bagian produk jadi atau bahan yang meskipun menjadi bagian produk jadi tetapi nilainya relatif kecil bila dibandingkan harga pokok produksi. Biaya bahan pembantu merupakan bahan pembantu secara tidak langsung membentuk terbentuknya produk, dan biaya relatif kecil jumlahnya.

2. Biaya reparasi dan pemeliharaan

Volume. 9/No. I/Januari 202I A1-Iqtishod|78 
Lukita Permanasari, Ayu Dwi Virdayani

Adalah part/ supplies yang di gunakan untuk pemeliharaan dan perbaikan suatu aset (aktiva) perusahaan.

Biaya reparasi dan pemeliharaan seperti biaya suku cadang (sparepart), bahan baku habis pakai (factory supplies) dan harga perolehan jasa dari pihak luar perusahaan untuk keperluan perbaikan dan pemeliharaan emplasemen, perumahan, bangunan perusahaan, mesin-mesin dan eqiupment, kendaraan, perkakas laboratorium dan aktiva tetap lain yang digunakan untuk keperluan perusahaan.

3. Biaya tenaga kerja tidak langsung

Definisi dari tenaga kerja tidak langsung adalah tenaga kerja prusahaan yang upahnya tidak dapat diperhitungkan secara langsung kepada produk tertentu. Biaya tenaga kerja tidak langsung seperti upah, tunjangan dan biaya kesejahteraan yang dikeluarkan merupakan karyawan tertentu yang bekerja dalam departemen produksi, karyawan administrasi perusahaan dan mandor. ${ }^{8}$

4. Biaya yang timbul sebagai akibat penilaian terhadap aktiva tetap

Biaya akibat penilaian aktiva tetap yaitu penyusutan atas suatu aktiva tetap, biaya-biaya yang termasuk dalam kelompok ini antara lain adalah biaya depresiasi emplasemen perusahaan, bangunan perusahaan, mesin dan ekuipmen, perkakas laboratorium, alat kerja dan aktiva tetap yang digunakan dalam perusahaan.

5. Biaya yang timbul sebagai akibat berlakunya waktu

Biaya yang termasuk dalam kelompok ini adalah biaya gedung dan emplasemen, asuransi mesin, dan ekipmen, asuransi kendaraan, asuransi kecelakaan karyawan

6. Biaya overhead pabrik lain yang secara langsung memerlukan pengeluaran uang tunai. Biaya overhead pabrik yang termasuk dalam kelompok ini

\footnotetext{
${ }^{8}$ Mulyadi,Akuntansi biaya,(Bandung:STIE, I99I),208.
}

Volume. 9/No. I/Januari 202I A1-Iqtishod|79 
Lukita Permanasari, Ayu Dwi Virdayani adalah biaya reparasi yang diserahkan kepada pihak luar dan biaya listrik PLN. ${ }^{9}$

\section{Ruang Lingkup Biaya Produksi}

Pengambilan keputusan khusus mempunyai jenis pengaruh keputusan yang dilakukan oleh manajemen, yang pada umumnya bersifat rutin dan tidak teratur waktu terjadinya. Ruang lingkup biaya produksi dalam pengambilan keputusan khusus terutama yang berkaitan dengan pemilihan alternatif antara lain:

I. menerima atau menolak pesanan khusus

2. menghentikan atau meneruskan jenis produk

3. membuat sendiri atau membeli bahan baku produksi

4. menyewakan atau menjual fasilitas perusahaan

5. menjual atau memproses lebih hasil produksi

6. penggantian aktiva tetap

Dari ruang lingkup biaya produksi diatas, penulis akan membahas lebih lanjut mengenai pengambilan keputusan khusus untuk menghentikan atau meneruskan jenis produk. ${ }^{10}$

\section{Analisis Kontribusi Laba}

Dalam jangka pendek dimana biaya produksi biasanya tetap dan oleh karena itu tidak terpengaruh oleh adanya pertambahan penjualan dan output, manajemen biasanya tertarik dengan pengaruh dari kebijakan-kebijakan tertentu terhadap laba. Analisis kontribusi laba ini menjelaskan hal tersebut. Kontribusi laba ini didefinisikan sebagai perbedaan antara penerimaan dengan biaya variabel (VC), hal ini berarti pula bahwa kontribusi laba adalah sama dengan harga (P) dikurangi biaya variabel rata-rata (AVC)per unit. ${ }^{1}$ Dari definisi diatas dapat diketahui rumus untuk menentukan laba sebagai berikut:

\footnotetext{
${ }^{9}$ Supomo, Akuntansi manajemen,(Yogyakarta:BPFE, 1990),24.

${ }^{10}$ Hartanto, Akuntasi untuk usahawan,(Jakarta:REUI, I98I), 83.

${ }^{11}$ Lincolin Arsyad, Ekonomi Manajerial,(Yogyakarta:BPFE,20I2)295.
}

Volume. 9/No. I/Januari 202I A1-Iqtishod| 80 
$\mathrm{Laba}=\mathrm{P}-\mathrm{AVC}$

\section{Metode Penentuan Harga Pokok}

Definisi metode penentuan harga pokok adalah cara untuk memperhitungkan unsur-unsur biaya ke dalam harga produksi. Pendekatan yang digunakan dalam menghitung harga pokok produksi adalah:

a. Full Costing. Adalah metode penentuan harga pokok produksi yang mempertimbangkan semua unsur biaya kedalam harga pokok produksi, yang terdiri dari biaya bahan baku, biaya tenaga kerja langsung dan biaya overhead pabrik, baik yang berperilaku variabel maupun tetap.

Unsur dalam menghitung harga pokok dengan Fuil Costing terdiri dari biaya bahan baku, biaya tenaga kerja langsung, biaya overhead pabrik variabel, dan biaya overhead pabrik tetap ditambah dengan biaya non produksi (biaya pemasaran, biaya administrasi dan umum).

b. Variabel Costing

Adalah penentuan harga pokok produksi yang hanya memperhitungkan biaya produksi yang berperilaku variabel kedalam harga pokok produksi, yang terdiri dari biaya bahan baku, biaya tenaga kerja langsung dan biaya overhead pabrik variabel.

Unsur dalam menghitung harga pokok produksi dengan variabel costing terdiri dari bahan baku, biaya tenaga kerja langsung dan terdiri dari biaya overhead pabrik variabel ditambah dengan biaya administrasi dan umum overhead, biaya tetap ( biaya overhead pabrik tetap, biaya pemasaran tetap, biaya administrasi dan umun tetap. ${ }^{12}$

\section{Proses Pengambilan Keputusan}

${ }^{12}$ Mulyadi, Akuntansi biaya,(Bandung:STIE, I99I), I8.

Volume. 9/No. I/Januari 202I A1-Iqtishod|8I 
Untuk membuat keputusan digunakan teori keputusan merupakan ilmu pengetahuan yang menjelaskan proses pembuatan keputusan, proses pengambilan keputusan dapat dibagi menjadi 4 yaitu:

a. Menentukan masalah dengan penekanan pada tujuan yang hendak dicapai.

Semua kegiatan proses pembuatan keputusan tergantung pada penentuan masalah. Tahap ini merupakan tahap yang paling sulit dari keseluruhan proses pembuatan keputusan. Manajemen harus mengidentifikasi data secara jelas masalah yang dihadapi.

b. Mengidentifikasi berbagai alternatif tindakan. Untuk membuat keputusan yang efektif, manajemen harus mengidentifikasi berbagai macam alternatif yang mungkin dipilih untuk menyelesaikan masalah, identifikasi alternatif pemecahan masalah merupakan gagasan dan inovasi yang berani dan kreatif.

c. Mendapatkan informasi yang relevan dan menyingkirkan informasi yang tidak relevan. Pembuatan keputusan memerlukan berbagai macam informasi yang dapat membantunya dalam membuat keputusan. Informasi tersebut dapat berasal dari dalam organisasi atau luar organisasi. Hanya informasi yang relevan yang dapat meningkatkan pemahaman atau menurunkan resiko ketidak pastian atas alternatif yang dipilih. Oleh sebab itu informasi yang tidak relevan dalam membuat keputusan harus ditiadakan.

d. Membuat keputusan. Dalam membuat keputusan tersebut tidak hanya diperhitungkan variabel tunggal yang harus dipertimbangkan berbagai macam variabel yang mendominasi masalah tersebut, jadi harus menggunakan kreteria interaksi banyak variabel.

\section{Metode Penelitian}

Penelitian ini menggunakan metode kualitatif karena data yang didapatkan di lapangan belum cukup memenuhi untuk dijadikan penelitian kuantitatif, ${ }^{13}$ yang

\footnotetext{
${ }^{13}$ Prof. Dr. Sugiyono, Metode Penelitian Bisnis. Pendekatan Kuantitatif, KualitatifDan R \& D, Bandung: Alfabeta, 2015.
}

Volume. 9/No. I/Januari 202I A1-Iqtishod | 82 
Lukita Permanasari, Ayu Dwi Virdayani menjadi objek penelitian adalah pihak home industri kecambah kaitannya dalam biaya produksi sebagai dasar pengambilan keputusan produksi dikarenakan sebagaian perusahaan kurang akan memperhatikan atau bahkan tidak memperhitungkan profitabilitas yang didapatkan oleh perusahaan sehingga tidak bisa menentukan tindakan untuk memproduksi lebih lanjut atau menghentikan jenis produksi yang dianggap tidak bisa memberikan laba yang signifikan bagi perusahaan.

Teknik pengumpulan data dilakukan terlebih dahulu melalui survei pendahuluan yang bertujuan untuk memperoleh gambaran mengenai masalah yang akan dibahas dan menentukan apa saja faktor - faktor yang terkait dan dapat digunakan dalam penelitian ini.kemudian melakukan studi kepustakaan dengan membaca literaturliteratur atau bahan-bahan penelitian untuk mendapat informasi yang tepat dan benar menyangkut landasan teori yang digunakan dalam penelitian. ${ }^{14}$ Langkah terakhir melalui pengumpulan data untuk mendapatkan data variabel-variabel yang akan diperoleh dari home industri kecambah melalui periode secara tahunan.

Dari data yang telah dikumpulkan kemudian diadakan pengolahan data dengan cara membuat perhitungan dengan menggunakan metode MOS (margin of safety)dengan langkah-langkah sebagai berikut:

I. Menentukan harga jual perunit produk

2. Menentukan biaya variabel perunit produk

3. Menentukan total biaya tetap per tahun

4. Menentukan margin of safety dengan rumus :

MOS $=$ rencana penjualan - penjualan impas

\section{Hasil dan Pembahasan}

${ }^{14}$ Ibid., 264.

Volume. 9/No. I/Januari 202I A1-Iqtishod|83 
Lukita Permanasari, Ayu Dwi Virdayani

Dalam penelitian ini, data yang telah dihimpun peneliti dari wawancara yang dilakukan dapat dikelompokkan dalam beberapa kelopok data yang selanjutnya dianalisis. Data yang dimaksud diatas adalah sebagai berikut :

I. Laporan laba rugi produksi kecambah kacang hijau dan kedelai tahun 2015 (tabel 4.1,4.2)

2. Laporan laba rugi produksi kecambah kacang hijau dan kedelai tahun 2016 (tabel $3,4)$

3. Perincian volume penjualan produksi kecambah kacang hijau dan kecambah kedelai untuk tahun 2015 dan 2016 (tabel 5,6)

4. Perincian volume produksi kecambah kacang hijau dan kecambah kedelai tahun 2015 (tabel 7,8)

5. Perincian volume produksi kecambah kacang hijau dan kecambah kedelai tahun 2016 (tabel 9,10)

\section{Laporan Laba Rugi Kecambah Kacang Hijau Dan Kedelai Tahun 2015}

Tabel 4.I laporan laba rugi produksi kecambah kacang hijau tahun 2015

\begin{tabular}{|l|l|l|}
\hline NO & NAMA AKUN & JUMLAH \\
\hline I & Hargapokokkacanghijau & 1.095 .000 .000 \\
\hline 2 & Gajipegawai & I 56.740 .000 \\
\hline 3 & Pemeliharaanmesin & 6.000 .000 \\
\hline 4 & Pemeliharaanbangunan & 3.600 .000 \\
\hline 5 & Listrik & 36.000 .000 \\
\hline 6 & Bahanpenolong & 3.600 .000 \\
\hline 7 & Biayapengangkutan & 25.550 .000 \\
\hline 8 & Biaya lain-lain & 3.600 .000 \\
\hline 9 & Pulsa & 18.00 .000 \\
\hline Jumlah biaya produksi & 1.331 .890 .000 \\
\hline
\end{tabular}

Volume. 9/No. I/Januari 202I A1-Iqtishod| 84 
Lukita Permanasari,

Ayu Dwi Virdayani

\begin{tabular}{|l|l|}
\hline Penjualan & I.368.750.000 \\
\hline Laba /Rugi & 36.860 .000 \\
\hline
\end{tabular}

Sumber data home industri kecambah Rama Hulaan

Tabel 4.2 laporan laba rugi produksi kecambah kedelai tahun 20 I5

\begin{tabular}{|l|l|l|}
\hline No & NamaAkun & Jumlah \\
\hline I & Hargapokokkedelai & $205.3 \mathrm{I} 2.500$ \\
\hline 2 & GajiPegawai & $\mathrm{I} 56.740 .000$ \\
\hline Jumlahbiayaproduksi & 362.052 .500 \\
\hline Penjualan & 410.625 .000 \\
\hline Laba/Rugi & 48.572 .500 \\
\hline
\end{tabular}

*Biaya pengeluaran yang lain mengikuti di produksi kecambah kacang hijau

Sumber data home industri kecambah Rama Hulaan

Dari tabel 4.I dapat diketahui bahwa laba dari penjualan kecambah kacang hijau pada tahun 2015 sebesar Rp.36.860.000, dan dari tabel 4.2 laba dari penjualan kecambah kacang kedelai Rp.48.572.500.

II. Laporan Laba Rugi Kecambah Kacang Hijau Dan Kedelai Tahun 2016

Tabel 4.3 laporan laba rugi produksi kecambah kacang hijau tahun 2016

\begin{tabular}{|l|l|l|}
\hline NO & NAMA AKUN & JUMLAH \\
\hline I & Hargapokokkacanghijau & $\mathrm{I} .533 .000 .000$ \\
\hline 2 & Gajipegawai & $\mathrm{I} 88.050 .000$ \\
\hline 3 & Pemeliharaanmesin & 8.400 .000 \\
\hline 4 & Pemeliharaanbangunan & 4.200 .000 \\
\hline 5 & Listrik & 48.000 .000 \\
\hline 6 & Bahanpenolong & 4.800 .000 \\
\hline 7 & Biayapengangkutan & 36.500 .000 \\
\hline 8 & Biaya lain-lain & 4.800 .000 \\
\hline
\end{tabular}

Volume. 9/No. I/Januari 202I A1-Iqtishod|85 
Lukita Permanasari,

Ayu Dwi Virdayani

\begin{tabular}{|l|l|l|}
\hline 9 & Pulsa & 3.600 .000 \\
\hline Jumlah biaya produksi & 1.831 .350 .000 \\
\hline Penjualan & 1.916 .250 .000 \\
\hline Laba / Rugi Sumber data home industri kecambah Rama Hulaan \\
\hline \multicolumn{2}{|l}{} \\
\hline
\end{tabular}

Tabel 4.4 laporan laba rugi produksi kecambah kedelai tahun 2016

\begin{tabular}{|l|l|l|}
\hline No & NamaAkun & Jumlah \\
\hline I & Hargapokokkedelai & 262.800 .000 \\
\hline 2 & GajiPegawai & I88.050.000 \\
\hline Jumlahbiayaproduksi & 450.850 .000 \\
\hline Penjualan & 525.600 .000 \\
\hline Laba/Rugi & 74.750 .000 \\
\hline
\end{tabular}

*Biaya pengeluaran yang lain mengikuti di produksi kecambah kacang hijau Sumber data home industri kecambah Rama Hulaan

Dari tabel 4.3 dapat diketahui bahwa laba dari penjualan kecambah kacang hijau pada tahun 2016 sebesar Rp.84.900.000, dan dari tabel 4.4 laba dari penjualan kecambah kacang kedelai Rp.74.750.000.

Dari data yang di dapat dari tabel 4.I dan tabel 4.3 terdapat selisih sebesar Rp. 48. 040.000 pada produksi kecambah kacang hijau, artinya terdapat kenaikan laba sebesar 57\%. Sedangkan pada produksi kecambah kedelai dari data yang didapat dari tabel 4.2 dan tabel 4.4 terdapat selisih sebesar Rp. 26.177.500, artinya terdapat kenaikan laba sebesar 35\%.

Dapat disimpulkan bahwa dalam setiap tahun terdapat kenaikan laba yang diperoleh perusahaan yang membuat perusahaan semakin berkembang pesat dan jumlah produksi dari tahun ke tahun semakin meningkat.

Volume. 9/No. I/Januari 202I A1-Iqtishod | 86 
Lukita Permanasari, Ayu Dwi Virdayani

III. Perincian Volume Penjualan Produksi KecambahKacang Hijau Dan Kedelai Tahun 2015-2016

Tabel 4.5 Perincian volume penjualan produksi kecambah kacang hijau untuk tahun 2015 dan 2016

\begin{tabular}{|l|l|l|l|}
\hline Nama Akun & 2015 & 2016 & Jumlah \\
\hline Kecambah kacang hijau & $547.500 \mathrm{~kg}$ & $638.750 \mathrm{~kg}$ & $1.186 .250 \mathrm{~kg}$ \\
\hline \multicolumn{3}{|l}{ h Sumber data home industri kecambah Rama Hulaan }
\end{tabular}

Tabel 4.6 Perincian volume penjualan produksi kecambah kedelai untuk tahun 2015 dan 2016

\begin{tabular}{|l|l|l|l|}
\hline Nama Akun & 2015 & 2016 & Jumlah \\
\hline $\begin{array}{l}\text { Kecambah } \\
\text { kedelai }\end{array}$ & $82.125 \mathrm{~kg}$ & $87.600 \mathrm{~kg}$ & $169.725 \mathrm{~kg}$ \\
\hline
\end{tabular}

Sumber data home industri kecambah Rama Hulaan

Dari tabel 4.5 dapat diketahui bahwa volume penjualan kecambah kacang hijau pada tahun 2015 dan 2016 terdapat kenaikan sebesar 91.250kg, dan dari tabel 4.6 laba dari penjualan kecambah kacang kedelai pada tahun 2015-20I6 terdapat kenaikan sebesar $5.475 \mathrm{~kg}$.

IV. Laporan Biaya Produksi Kecambah Kacang Hijau Dan Kedelai Tahun 2015

Tabel 4.7 laporan biaya produksi kecambah kacang hijau Tahun 2015

\begin{tabular}{|l|l|l|}
\hline NO & NAMA AKUN & JUMLAH \\
\hline I & Hargapokokkacanghijau & 1.095 .000 .000 \\
\hline 2 & Gajipegawai & I56.740.000 \\
\hline 3 & Pemeliharaanmesin & 6.000 .000 \\
\hline 4 & Pemeliharaanbangunan & 3.600 .000 \\
\hline
\end{tabular}


Lukita Permanasari,

Ayu Dwi Virdayani

\begin{tabular}{|l|l|l|}
\hline 5 & Listrik & 36.000 .000 \\
\hline 6 & Bahanpenolong & 3.600 .000 \\
\hline 7 & Biayapengangkutan & 25.550 .000 \\
\hline 8 & Biaya lain-lain & 3.600 .000 \\
\hline 9 & Pulsa & 18.00 .000 \\
\hline Jumlah biaya produksi & 1.331 .890 .000 \\
\hline
\end{tabular}

Sumber data home industri kecambah Rama Hulaan

Tabel 4.8 laporan biaya produksi kecambah kedelai tahun 2015

\begin{tabular}{|l|l|l|}
\hline No & NamaAkun & Jumlah \\
\hline I & Hargapokokkedelai & 205.312 .500 \\
\hline 2 & GajiPegawai & I56.740.000 \\
\hline \multicolumn{2}{|l|}{ Jumlahbiayaproduksi } & 362.052 .500 \\
\hline
\end{tabular}

Sumber data home industri kecambah Rama Hulaan

V. Laporan Biaya Produksi Kecambah Kacang Hijau Dan Kedelai Tahun 2016

Tabel 4.9 Laporan biaya produksi kecambah kacang hijau tahun 2016

\begin{tabular}{|l|l|l|}
\hline NO & NAMA AKUN & JUMLAH \\
\hline I & Hargapokokkacanghijau & I.533.000.000 \\
\hline 2 & Gajipegawai & $\mathrm{I} 88.050 .000$ \\
\hline 3 & Pemeliharaanmesin & 8.400 .000 \\
\hline 4 & Pemeliharaanbangunan & 4.200 .000 \\
\hline 5 & Listrik & 48.000 .000 \\
\hline 6 & Bahanpenolong & 4.800 .000 \\
\hline 7 & Biayapengangkutan & 36.500 .000 \\
\hline 8 & Biaya lain-lain & 4.800 .000 \\
\hline 9 & Pulsa & 3.600 .000 \\
\hline
\end{tabular}

Volume. 9/No. I/Januari 202I A1-Iqtishod | 88 
Lukita Permanasari,

Ayu Dwi Virdayani

Jumlahbiayaproduksi

I.83I.350.000

Sumber data home industri kecambah Rama Hulaan

Tabel 4.I0 Laporan biaya produksi kecambah kacang kedelai tahun 2016

\begin{tabular}{|l|l|l|}
\hline No & NamaAkun & Jumlah \\
\hline I & Hargapokokkedelai & 262.800 .000 \\
\hline 2 & GajiPegawai & I88.050.000 \\
\hline Jumlah biaya produksi & 450.850 .000 \\
\hline
\end{tabular}

Sumbe Sumber data home industri kecambah Rama Hulaan

Dari tabel 4.7 dan 4.9dapat diketahui bahwa biaya produksi kecambah kacang hijau pada tahun 2015 dan 2016 terdapat kenaikan sebesar Rp. 499.460.000, dan dari tabel 4.8 dan 4.10 dapat diketahui bahwa biaya produksi kecambah kedelai terdapat kenaikan sebesar Rp. 88.798.000.

Sebagaimana yang telah dijelaskan dimuka bahwa hasil produksi dari home industri Kecambah Rama Hulaan Gresik yaitu berupa sayuran yang berasal dari olahan kacang-kacangan yang disebut dengan kecambah kacang hijau dan kecambah kedelai yang banyak digunakan masyarakat dalam campuran masakan yang di dalamnya juga banyak mengandung vitamin $\mathrm{E}$ itu tidaklah berjalan dengan mudah, seringkali pihak manajemen perusahaan dihadapkan pada beberapa alternatif pengambilan keputusan untuk meminimalisir resiko kerugian yang dihadapi perusahaan.

Faktor-faktor yang menyebabkan peningkatan laba secara riil pada produksi kecambah kacang hijau dan kecambah kedelai pada Home Industri Kecambah Rama Hulaan Gresik adalah:

I. Kenaikan biaya produksi kecambah dari tahun ke tahun diikuti oleh meningkatnya volume produksi.

2. Adanya kenaikan penjualan, hal ini disebabkan karena perusahaan mampu mengelola dalam hal harga dimana biaya-biaya yang digunakan semakin naik dan diikuti harga produksi yang ikut meningkat.

Volume. 9/No. I/Januari 202I A1-Iqtishod | 89 
Lukita Permanasari, Ayu Dwi Virdayani

3. Perusahaan mampu menerapkan analisa biaya dalam mengambil keputusan menghentikan atau meneruskan produksi kecambah.

Perusahaan yang dihadapkan pada masalah untuk memilih dari dua alternatif yaitu menambah jumlah produksi atau menetapkan jumlah produksi yang bisa menambah peningkatan laba. Dari dua alternatif pengambilan keputusan tersebut perusahaan harus lebih teliti untuk memperhitungkan keputusan yang lebih menguntungkan untuk diambil. Kesalahan dalam pengambilan keputusan akan mengakibatkan penurunan laba pada perusahaan. Untuk memecahkan masalah perlu dianalisis dari kedua alternatif tersebut mana yang lebih menguntungkan, menambah jumlah produksi atau menetapkan jumlah produksi kecmbah dengan melakukan pendekatan biaya produksi. Berikut akan disajikan perhitungan kontribusi laba.

I. Laba produksi kecambah kacang hijau pada tahun 2015

$$
\begin{aligned}
\text { Laba } & =\text { P }- \text { AVC } \\
\text { Laba } & =1.368 .750 .000-\text { I.33I.890.000 } \\
& =36.860 .000
\end{aligned}
$$

Dari perhitungan laba yang diperoleh sebesar Rp. 36.860.000 diketahui dari harga penjualan (P) Rp.I.368.750.000 dikurangi dengan biaya variabel rata-rata (AVC) yang diglobalkan menjadi satu di dalam biaya produksi sebesar R p.I.331.890.000

II. Laba produksi kecambah kedelai pada tahun 2015

$$
\begin{aligned}
\text { Laba } & =P-A V C \\
\text { Laba } & =410.625 .000-362.052 .500 \\
& =48.572 .500
\end{aligned}
$$

Dari perhitungan laba yang diperoleh sebesar Rp. 48.572 .500 diketahui dari harga penjualan (P) Rp.4I0.625.000 dikurangi dengan biaya variabel rata-rata (AVC) yang diglobalkan menjadi satu di dalam biaya produksi sebesar Rp.362.052.500

III. Laba produksi kecambah kacang hijau pada tahun 2016

Volume. 9/No. I/Januari 202I A1-Iqtishod|90 
$\mathrm{Laba}=\mathrm{P}-\mathrm{AVC}$

$$
\begin{aligned}
\text { Laba } & =\text { I.9I6.250.000 - I.83I.350.000 } \\
& =84.900 .000
\end{aligned}
$$

Dari perhitungan laba yang diperoleh sebesar Rp. 84.900.000 diketahui dari harga penjualan (P) Rp.I.916.250.000 dikurangi dengan biaya variabel rata-rata (AVC) yang diglobalkan menjadi satu di dalam biaya produksi sebesar Rp.I.83I.350.000

IV. Laba produksi kecambah kedelai tahun 2016

$$
\begin{aligned}
\text { Laba } & =P-A V C \\
\text { Laba } & =525.600 .000-450.850 .000 \\
& =74.750 .000
\end{aligned}
$$

Dari perhitungan laba yang diperoleh sebesar Rp.525.600.000 diketahui dari harga penjualan (P) Rp.450.850.000 dikurangi dengan biaya variabel rata-rata (AVC) yang diglobalkan menjadi satu di dalam biaya produksi sebesar Rp.74.750.000

Dapat disimpulkan dari data yang telah disajikan bahwa Home Industri Kecambah Rama Hulaan mengalami kenaikan laba dan kenaikan jumlah produksi dari tahun ke tahun sehingga perusahaan terus mengalami kemajuan semakin meningkat dan pihak manajemen bisa mengambil keputusan untuk menambah jumlah produksi di tahun yang akan datang dan dibarengi semakin bertambahnya laba yang akan di dapat oleh perusahaan.

\section{E. Simpulan}

Adanya keuntungan yang terjadi pada produksi kecambah yang disebabkan meningkatnya penjualan dan jumlah produksi menjadikan Home Industri Kecambah 
Lukita Permanasari, Ayu Dwi Virdayani Rama Hulaan mengambil keputusan antara menambah jumlah produksi kecambah atau menetapkan jumlah produksi. Diantara dua alternatif tersebut harus dipilih salah satu yang menguntungkan bagi perusahaan. Bila perusahaan memutuskan untuk menambah jumlah produksi maka akan bertambah pula biaya produksi dan semakin meningkatnya laba yang akan diperoleh oleh perusahaan. Dan jika perusahaan menetapkan jumlah produksi maka tidak ada kenaikan biaya produksi begitu pula tidak ada kenaikan laba di tahun yang akan datang. Dari analisa perbandingan antara menambah atau menetapkan jumlah produksi sebaiknya perusahaan mengambil keputusan untuk menambah jumlah kecambah yang di produksi.

\section{F. Daftar Pustaka}

Dewan Standar Akuntansi Syariah IAI. "Standar Akuntansi Keuangan Syariah.” Ikatan Akuntan Indonesia, 2016.

Kambali, Muhammad. "Paradigma Sistem Kapitalisme Dan Islam Tentang Welfare State." JES (Jurnal Ekonomi Syariah), 2019. https.// doi.org/I0.30736/jesa.v4iI.55.

Sarwono, Hartadi A. "Profil Bisnis Usaha Mikro, Kecil Dan Menengah (Umkm).” Bank Indonesia Dan LPPI, 2015.

Sugiyono, Prof. Dr. Metode Penelitian Bisnis. Pendekatan Kuantitatif, Kualitatif Dan $R$ \& D. Bandung: Alfabeta, 2015.

Prathama Manurung, Pengantar IImu Ekonomi,(Jakarta: Lembaga Penerbit fakultas Ekonomi Universitas Indonesia,2008)

Sadono Sukirno, Mikro EkonomiTeori Pengantar, (Jakarta: Rajawali Pers, 2009)

Mulyadi, Akuntansi Biaya,(Bandung:STIE,I99I)

Supomo,Akuntansi manajemen,(Yogyakarta:BPFE,1990)

Hartanto,Akuntasi untuk usahawan,(Jakarta:REUI,I98I)

Lincolin Arsyad, Ekonomi Manajerial,(Yogyakarta:BPFE,20I2)

Volume. 9/No. I/Januari 202I A1-Iqtishod|92 